\title{
IMPACT OF QUANTITATIVE EVALUATION METHODS ON THE QUALITY OF SCIENTIFIC RESEARCH CONDUCTED BY UNIVERSITY TEACHERS
}

ABSTRACT. The theoretical part of this paper analyzes the issue of professional development of university teachers in the context of lifelong learning, points out the character of currently used methods of evaluation of their scientific research, as well as the importance and effects of legislation that deals with quantitative methods for the evaluation of scientific research conducted by university teachers and associates.

The methodological framework of the research is based on the research goal focused on examining opinions of teachers and associates at teacher training faculties about the contribution of quantitative evaluation methods of scientific research conducted to the quality of professional development and scientific research of teachers and associates at teacher training faculties with respect to a) belonging to the university where they are employed, b) experience, c) gained scientific degree, d) the number of papers published on the SCI list.

1 d.vasilijevic@sbb.rs

This paper is a part of the project "Teaching and Learning: Issues, Objectives and Perspectives", $\mathrm{N}^{\circ} 179026$, supported by the Republic of Serbia's Ministry of Education and Science.

This paper was submitted on July 6, 2016 and accepted for publication at the meeting of the Editorial Board held on September 29, 2016. 
The overall objective of the research was realized through two research objectives: 1) to examine how teachers at teacher training faculties perceive the impact of quantitative methods for the evaluation of scientific research on the quality of their own scientific research; 2) to establish how teachers see the correlation between the quality of scientific research and normative acts of the university related to election and appointment to teaching positions; 3) to determine whether and to what extent existing quantitative evaluation methods affect the autonomy of researchers in terms of the choice of their research content and time dynamics. By implementing the descriptive method, Likert attitude scale, we examined and analyzed the attitudes of 97 teachers and associates at teacher training faculties in Užice, Belgrade, Vranje and Jagodina. Results show that, in the opinion of teachers and associates at teacher training faculties, quantitative evaluation methods do contribute to the quality of teaching and professional development of both teachers and associates, but not to a sufficient extent.

KEY WORDS: professional development of teachers, scientific research, evaluation, quantitative evaluation methods, quality of work.

\section{INTRODUCTORY DISCUSSION}

The age we live in is characterized by rapid development of information and other technologies, which requires continuous professional development. The idea of a permanent, prolonged and continuous education arose from the understanding that education is a continuous process, necessary to maintain a man as a social individual, just as biochemical processes (such as breathing and feeding) are necessary for the sustenance and development of every organism (Jovanović Ilić, 1971, p. 11). Intensive changes in the fields of economy, science and culture are closely related to changes in the structure of education system. Drastic quantitative and qualitative changes in the aforementioned areas that are not supported and followed by equally intensive changes in education system create "formally educated" members of society who are often insufficiently capable of active and creative participation in daily life (Vasilijević, 2010, p. 11).

Research conducted during 1970s proves that institutional education becomes outdated every four years and that no level of qualification can give a professionally engaged person everything they need during their entire professional career (Prodanović, 1971, p. 62). Back then, this term was defined as the idea of a continuous education which was embedded in theories of educa- 
tion and named knowledge society. In the next decade, this concept was named continuing education and the term lifelong learning first appeared in the last decade of the $20^{\text {th }}$ century.

Lifelong learning implies a continuous process that should last throughout one's entire life and in different circumstances, depending on one's professional and personal needs. The European Commission adopted the Lifelong Learning Programme in 2004 for the period between 2007 and 2013 which deals with learning in all periods of life. The Memorandum about lifelong learning promotes six basic principles for the implementation of lifelong learning in practice:

1) to guarantee universal and continuing access to learning for gaining and renewing the skills needed for sustained participation in the knowledge society;

2) to visibly raise levels of investment in human resources;

3) to develop effective teaching and learning methods and contexts for the continuum of lifelong and life-wide learning;

4) to significantly improve the ways in which learning participation and outcomes are understood and appreciated, particularly nonformal and informal learning;

5) to ensure that everyone can easily access good quality information and advice about learning opportunities throughout Europe and throughout their lives;

6) to provide lifelong learning opportunities as close to learners as possible, in their own communities wherever appropriate.

The Commission adopted projects within this program relating to professional development of teachers. The objective of the Socrates project is to develop a network of research centers that would help record the needs related to increased contribution of education and teacher training, whereas the Leonardo da Vinci project is focused on exchanging experiences in the field of in-service training at European level.

The term lifelong learning draws attention to the period of learning which spans one's entire life, either continuously or occasionally. Lifelong learning refers to the acquisition of all kinds of skills, knowledge and qualifications of children, youngsters and adults and encompasses all forms of learning. Continuing (or permanent) education which has been recently defined as lifelong learning refers to the period after the completion of formal educa- 
tion. It depends on the quality of primary education the purpose of which is to provide the conditions (work habits, motivation) for developing a positive attitude toward learning, which will later be reflected in one's relationship toward professional development.

The term life-wide, which can be encountered in various documents issued by the European Union refers to lifelong learning associated with different time and different places in which teaching and learning take place. This type of learning occur in everyday life, family, during leisure time, in various life situations. Learning in different life contexts, i.e. the concept of lifelong learning is implemented through formal, non-formal and informal education.

In the context of lifelong learning, teacher education and training are nowadays defined as professional development of teachers. Professional development is a broader concept than career development or in-service training (which is just one of system measures utilized in teacher development) and refers to the long-term process that involves various opportunities and experiences systematically planned the purpose of which is to improve professional growth and development of teachers (Ivić, Pešikan \& Antić, 2003, p. 62).

\section{APPROACH TO THE PROBLEM}

By accepting the Bologna Declaration, universities, including the faculties they comprise, are obligated to design new procedures for monitoring and evaluation of faculties in order to improve the overall quality of their faculties and the quality of all aspects of their operation, particularly continuous professional development of teachers as an important requirement of the quality of scientific research at the institution and the quality of teaching at all academic levels. In accordance with the new educational policy, quantitative methods for the evaluation of scientific research represent an important requirement of their professional development defined both in state legislation and university acts, especially in rules and regulations on self-assessment and quality review of higher education institutions and regulations on election and appointment of teachers and associates.

The idea of education system evaluation is not new. Even before the implementation of the Bologna Declaration, it was insisted on the internal, not external evaluation, its informative, motivational 
and regulatory function as opposed to its control function, qualitative and not quantitative evaluation methods. The importance of formative in relation to summative approach to evaluation was acknowledged (Pešić, 1998; Potkonjak, 1972; Hebib, 1995). The extent to which existing legislation meets the defined standards evaluation and self-evaluation standards of education system can certainly be the subject of expert analysis. For example, rules and regulations on self-assessment and quality review of higher education institutions explicitly state, among other things, that the higher education institution should encourage its employees to actively participate in scientific research, artistic and expert projects, as well as to actively incorporate knowledge acquired during scientific research and artistic activities into the existing teaching process. These regulations recognize the motivational function of evaluation, but not its character, i.e. type of motivation, which can be intrinsic and extrinsic. It is similar with regulations on election and appointment of teachers and associates, because we can ask how much conditional quantitative criteria for the level of teacher professional development and quantitative indicators of scientific research quality essentially contribute to the overall development of teachers' professional competences and therefore to the quality of instruction at all academic levels, from undergraduate to doctoral studies (Vasilijević, Sudzilovski, 2016, p. 140).

Professional development is a very complex process that requires teachers, preschool teachers and expert associates to continuously develop their competences in order to improve the quality of teaching, student development and their achievement (Regulations on Continuous Professional Development and Appointment of Teachers, Preschool Teachers and Expert Associates, 2012). Professional competences of the $21^{\text {st }}$ century teachers are in the focus of numerous EU documents (Education and Training, 2010; Work Programme, 2004) and are commonly associated with three categories: key competences, basic competences and special competences (Marinković, 2010).

Professional development of teachers includes experiences from initial teacher training, period of internship, in-service training, career development and professional advancement (Stanković, Pavlović, 2010). It is a comprehensive and continuous learning process which requires a permanent change of attitude toward one's own teaching practice (Grandić, Stipić, 2011). 


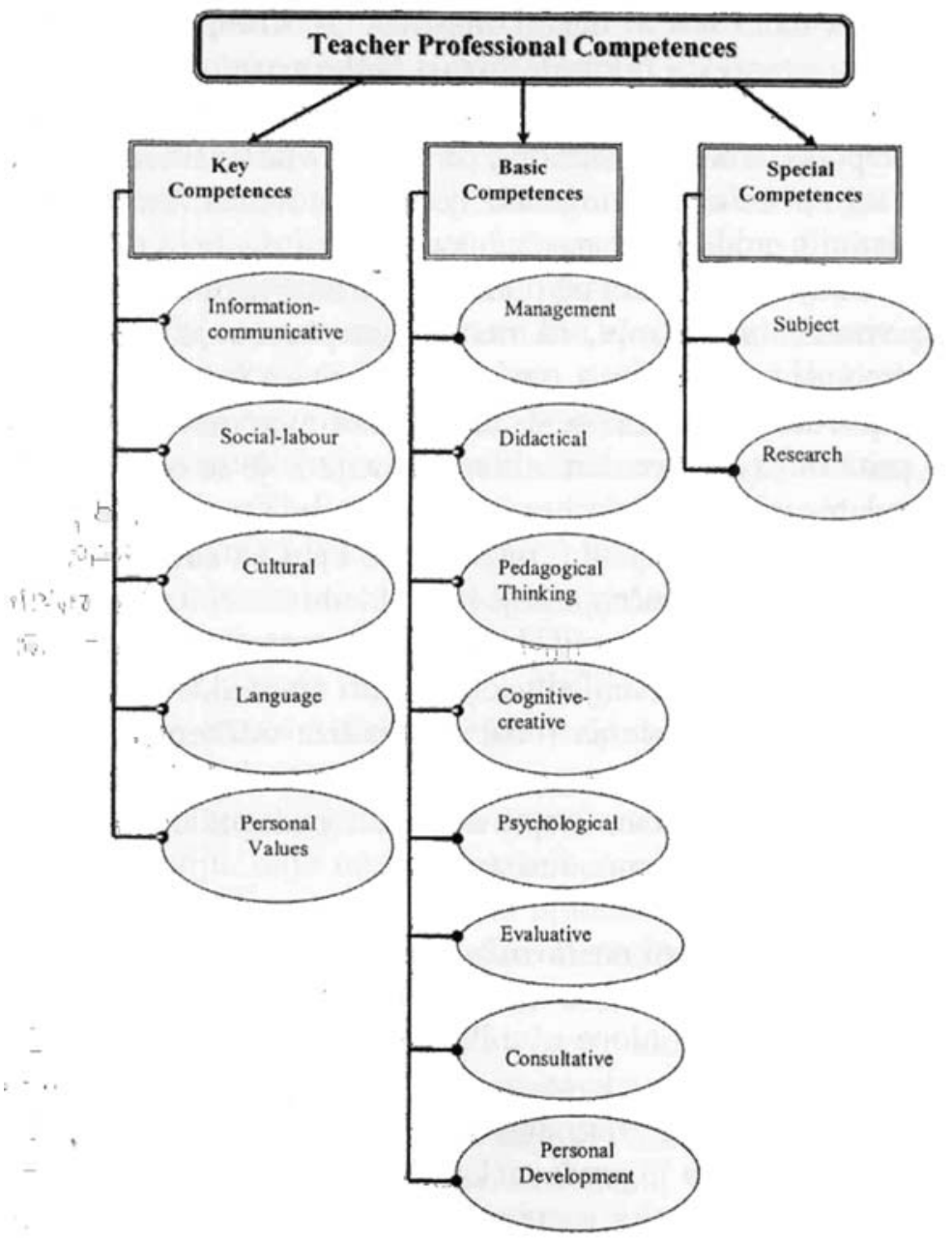

Figure 1: Professional Competences of teachers (OGIENKo, RolyaK, 2009)

The objective of professional development is to improve one's teaching practice, their professional competences, and therefore the overall quality of education system.

One of the important segments of professional work and development of the university teacher is scientific research in the field of his scientific expertise, because it represents a key indicator of the level of development and developmental processes of his professional and scientific competences and expertise.

On the theoretical basis of the study - Problems of innovation in the work of university professors by Zoran Avramović (2014), the 
empirical findings of Alibabić (2010), Popović, Vujisić Živković (2012) and Vasilijević, Sudzilovski (2016), and those who have established a methodological framework of the research.

The quantitative approach to evaluating the quality of scientific research work of university teachers includes teal range of subthemes, such as the issue of academic freedom, different criteria evaluating the quality of scientific research and etc. The authors agree that it is very important to have the most comprehensive and reliable overview of all the difficulties and dilemmas that accompany the quantitative method of evaluation research in all areas of education. Hence the perception of this phenomenon from the perspective of university teachers unavoidable. Unfortunately, the extensive research approach to this problem is still relevant.

\section{METHODOLOGICAL FRAMEWORK OF THE RESEARCH}

Our research is focused on quantitative methods for the evaluation of scientific research, the purpose of which is the overall professional development of teachers and the quality of teaching at university level. For these reasons, we conducted a research that examines attitudes of teachers and associates at teacher training faculties about the contribution of quantitative evaluation methods scientific research conducted to the quality of professional development and the quality of scientific research conducted by teachers and associates at teacher training faculties with respect to a) belonging to the university where they are employed, b) experience, c) gained scientific degree, d) the number of papers published on the SCI list.

Three research tasks branched out from the overall research objective: 1) to examine how teachers at teacher training faculties perceive the impact of quantitative methods for the evaluation of scientific research on the quality of their own scientific research;2) to establish how teachers perceive the connection between the quality of scientific research and the normative acts of the university related to their own professional development; 3 ) to determine whether and to what extent existing quantitative evaluation methods affect the autonomy of researchers in terms of the choice of their research content and time dynamics. We used the Likert attitude scale to examine the attitudes of 97 teachers and associates at teacher training faculties in Užice, Belgrade, Vranje and Jagodina. 
Basic research is the instrument before using basic psychometric properties (validity, reliability, discrimination and objectivity). The coefficient of the discriminative values of each of items in relation to the other items were in the range of 0.22 to 0.36 . Reliability was checked by calculating the Pearson correlation coefficient between the two halves of the instrument, resulting in 0.87 . Objectivity is checked by calculating the correlation coefficient score of three independent expert appraisers and amounted to 0.94 .

Independent variables of the research are the following: university where the respondents are elected to teaching positions (University of Kragujevac, University of Belgrade and University of Niš); years of professional experience (4 variants: 1 to 5,5 to 10,10 to 20 and 20 and more); academic rank (3 variants: associate and teaching fellow, docent, associate professor and tenured professor); number of published papers (4 variants: up to 10,10 to 20,20 to 50, 50 and more); number of published papers on the SCI list (3 variants: 0,1 to 5 and 5 and more).

Data obtained in the research were processed with the SPSS software package and statistical significance was determined by calculating the Chi-square at 0,01 and 0,05 levels of significance.

\title{
INTERPRETATION OF RESEARCH RESULTS
}

\author{
A) QUANTITATIVE EVALUATION METHODS \\ AND THE QUALITY OF SCIENTIFIC RESEARCH
}

Results show that a little more than a third, or $36,08 \%$ of university teachers and associates have a positive attitude toward the impact of quantitative evaluation methods on the quality of scientific research. The same percentage of respondents is undecided. However, slightly more than a quarter of teachers and associates at teacher training faculties $(27,84 \%)$ perceive this impact as negative.

Independent research variables did not affect the final results of this part of the research. Teachers and associates from different universities, with different professional experience, academic ranks and bibliographic opus do not differ in their evaluation of the impact of existing quantitative methods for the evaluation of scien- 


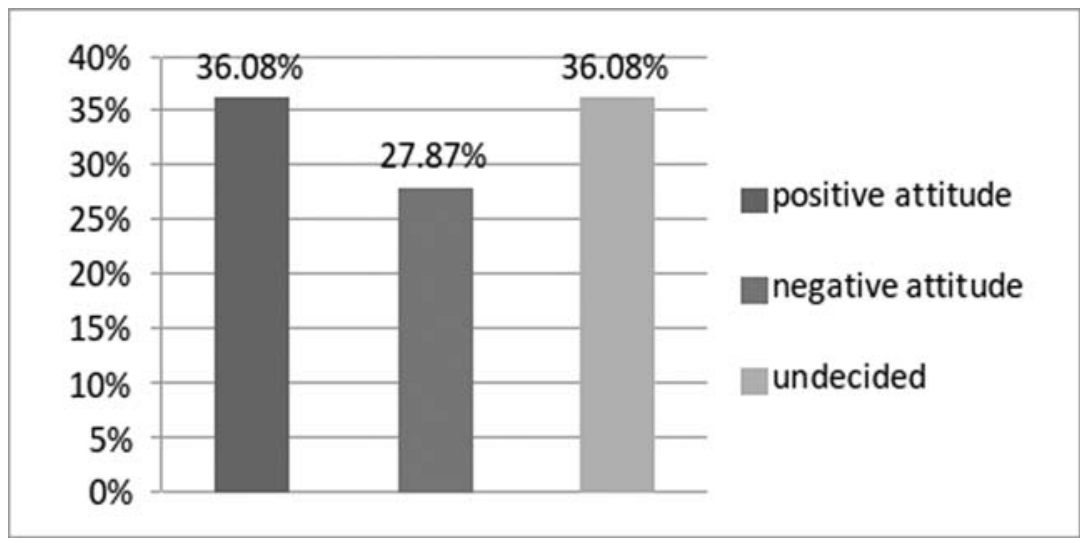

CHART 1: QUANTITATIVE EVALUATION METHODS AND THE QUALITY OF SCIENTIFIC RESEARCH

tific research on the professional development and quality of their own scientific research.

\begin{tabular}{|c|c|c|c|c|c|}
\hline \multirow{2}{*}{$\begin{array}{c}\text { ATTITUDES/INDEPENDENT } \\
\text { VARIABLES }\end{array}$} & & NEGATIVE & UNDECIDED & Positive & \multirow{2}{*}{$\begin{array}{l}\text { STATISTICAL } \\
\text { INDICATORS }\end{array}$} \\
\hline & & $\%$ & $\%$ & $\%$ & \\
\hline \multirow{3}{*}{ UNIVERSITY } & KRAGUJEVAC & $\begin{array}{l}9 \\
33,33\end{array}$ & $\begin{array}{l}14 \\
40,00\end{array}$ & $\begin{array}{l}14 \\
34,29\end{array}$ & \multirow{3}{*}{$\begin{array}{c}\mathrm{X} 2=1.676 \\
\mathrm{DF}=4 \\
\mathrm{P}=0.79\end{array}$} \\
\hline & BELGRADE & $\begin{array}{l}13 \\
48,15\end{array}$ & $\begin{array}{l}12 \\
34,29\end{array}$ & $\begin{array}{l}15 \\
42,87\end{array}$ & \\
\hline & Niš & $\begin{array}{l}5 \\
18,52\end{array}$ & $\begin{array}{l}9 \\
25,71\end{array}$ & $\begin{array}{l}6 \\
17,14\end{array}$ & \\
\hline \multirow{4}{*}{$\begin{array}{c}\text { YEARS OF PROFESSIONAL } \\
\text { EXPERIENCE }\end{array}$} & $1-5$ & $\begin{array}{l}6^{6} \\
2,23\end{array}$ & $\begin{array}{l}7 \\
20,00\end{array}$ & $\begin{array}{l}9 \\
25,71\end{array}$ & \multirow{4}{*}{$\begin{array}{c}\mathrm{X} 2=8.485 \\
\mathrm{DF}=6 \\
\mathrm{P}=0.20\end{array}$} \\
\hline & $5-10$ & $\begin{array}{l}5 \\
18,52\end{array}$ & $\begin{array}{l}10 \\
28,57\end{array}$ & $\begin{array}{l}10 \\
28,57\end{array}$ & \\
\hline & $10-20$ & $\begin{array}{l}14 \\
1,85\end{array}$ & $\begin{array}{l}12 \\
34,29\end{array}$ & $\begin{array}{l}7 \\
20,00\end{array}$ & \\
\hline & 20 AND MORE & $\begin{array}{l}2 \\
7,41\end{array}$ & $\begin{array}{l}6 \\
17,14\end{array}$ & $\begin{array}{l}9 \\
25,71\end{array}$ & \\
\hline
\end{tabular}

TABLE 1: QUANTITATIVE EVALUATION METHODS OF TEACHERS CONTRIBUTE TO THE QUALITY OF SCIENTIFIC RESEARCH 
Collection of Papers of the Faculty of Philosophy XLVI (3)/2016

\begin{tabular}{|c|c|c|c|c|c|}
\hline \multirow{3}{*}{ ACADEMIC RANK } & $\begin{array}{c}\text { ASSOCIATES } \\
\text { AND TEACHING } \\
\text { FELLOWS }\end{array}$ & $\begin{array}{l}12 \\
44,44\end{array}$ & $\begin{array}{l}10 \\
37,04\end{array}$ & $\begin{array}{l}5 \\
18,52\end{array}$ & \multirow{3}{*}{$\begin{array}{c}\mathrm{X} 2=1.353 \\
\mathrm{DF}=4 \\
\mathrm{P}=0.85\end{array}$} \\
\hline & DOCENTS & $\begin{array}{l}10 \\
37,04\end{array}$ & $\begin{array}{l}9 \\
25,71\end{array}$ & $\begin{array}{l}12 \\
34,29\end{array}$ & \\
\hline & $\begin{array}{c}\text { ASSOCIATE } \\
\text { PROFESSORS } \\
\text { AND TENURED } \\
\text { PROFESSORS }\end{array}$ & $\begin{array}{l}5 \\
8,52\end{array}$ & $\begin{array}{l}7 \\
20,00\end{array}$ & $\begin{array}{l}5 \\
14,28\end{array}$ & \\
\hline \multirow{4}{*}{$\begin{array}{c}\text { NUMBER OF PUBLISHED } \\
\text { PAPERS }\end{array}$} & UP TO 10 & $\begin{array}{l}7_{5,93} \\
\text {. }\end{array}$ & $\begin{array}{l}10 \\
28,57\end{array}$ & $\begin{array}{l}15 \\
42,85\end{array}$ & \multirow{4}{*}{$\begin{array}{c}X 2=11.964 \\
D F=6 \\
P=0.06\end{array}$} \\
\hline & $10-20$ & $\begin{array}{l}4 \\
14,81\end{array}$ & $\begin{array}{l}9 \\
25,71\end{array}$ & $\begin{array}{l}7 \\
20,00\end{array}$ & \\
\hline & $20-50$ & $\begin{array}{l}13 \\
48,15\end{array}$ & $\begin{array}{l}11 \\
31,43\end{array}$ & $\begin{array}{l}4 \\
11,42\end{array}$ & \\
\hline & 50 AND MORE & $\begin{array}{l}3 \\
1,11\end{array}$ & $\begin{array}{l}5 \\
14,29\end{array}$ & $\begin{array}{l}9 \\
25,71\end{array}$ & \\
\hline IN TOTAL & & $\begin{array}{c}27 \\
27,84\end{array}$ & $\begin{array}{c}35 \\
36,08\end{array}$ & $\begin{array}{c}35 \\
36,08\end{array}$ & \\
\hline
\end{tabular}

TABLE 1: QUANTITATIVE EVALUATION METHODS OF TEACHERS CONTRIBUTE TO THE QUALITY OF SCIENTIFIC RESEARCH

Б) EXTRINSIC MOTIVATION AND THE QUALITY OF SCIENTIFIC RESEARCH

The second research task is to examine the connection between the quality of scientific research and normative acts of the university related to elections for teaching positions. Namely, respondents assessed the following statement: extrinsic motivation drives university teachers and associates (rulebook on the appointment to 
teaching posts, criteria for participation in scientific projects, etc.) to improve the quality of their scientific research.

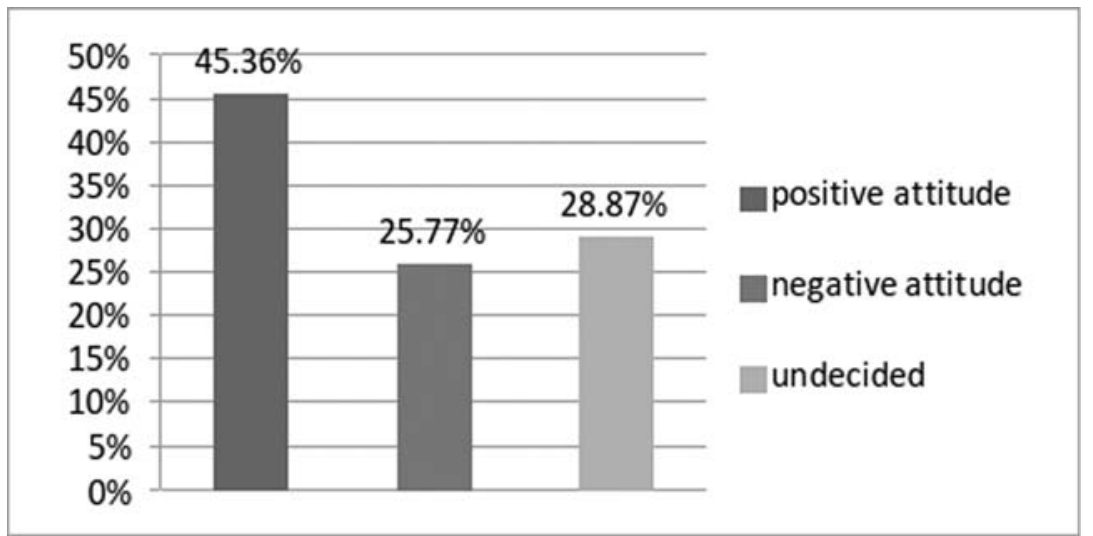

CHART 2: EXTRINSIC MOTIVATION AND THE QUALITY OF RESEARCH

It turned out that only $45,36 \%$ (less than a half) respondents positively assess this statement and that slightly more than one quarter, or $28,87 \%$, is undecided about it. The percentage of teachers with a negative attitude is not negligible either - it is one quarter $(25,77 \%)$.

We also wanted to learn if independent variables: university, professional experience, academic rank, number of published papers, as well as number of published papers on the CSI list are in any way related to the final results of this research.

It is interesting that these results match the results of the previous research task. Namely, respondents were unanimous in their assessment that there is a correlation between the quality of scientific research and normative acts of the university related to professional development. Therefore, independent variables have proved statistically insignificant.

\begin{tabular}{|c|c|c|c|c|c|c|c|}
\hline \multirow{2}{*}{$\begin{array}{l}\text { ATTITUDES/ } \\
\text { INDEPENDENT } \\
\text { VARIABLES }\end{array}$} & \multicolumn{2}{|c|}{ NEGATIVE } & \multicolumn{2}{|c|}{ UNDECIDED } & \multicolumn{2}{|c|}{ Positive } & \multirow{2}{*}{$\begin{array}{l}\text { STATISTICAL } \\
\text { INDICATORS }\end{array}$} \\
\hline & $\mathrm{F}$ & $\%$ & $\mathrm{~F}$ & $\%$ & $\mathrm{~F}$ & $\%$ & \\
\hline
\end{tabular}

TABLE 2: EXTRINSIC MOTIVATION AND THE QUALITY OF SCIENTIFIC RESEARCH 
Collection of Papers of the Faculty of Philosophy XLVI (3)/2016

\begin{tabular}{|c|c|c|c|c|c|}
\hline \multirow{3}{*}{ UNIVERSITY } & KRAGUJEVAC & $\begin{array}{c}12 \\
48,00\end{array}$ & $\begin{array}{c}12 \\
42,85\end{array}$ & $\begin{array}{c}13 \\
29,55\end{array}$ & \multirow{3}{*}{$\begin{array}{c}\mathrm{X} 2=2.838 \\
\mathrm{DF}=4 \\
\mathrm{P} \quad 0.58\end{array}$} \\
\hline & BELGRADE & $\begin{array}{c}9 \\
36,00\end{array}$ & $\begin{array}{c}10 \\
35,72\end{array}$ & $\begin{array}{c}21 \\
47,73\end{array}$ & \\
\hline & Niš & $\begin{array}{c}4 \\
16,00\end{array}$ & $\begin{array}{c}6 \\
21,43\end{array}$ & $\begin{array}{c}10 \\
22,73\end{array}$ & \\
\hline \multirow{4}{*}{$\begin{array}{c}\text { YEARS OF } \\
\text { PROFESSIONAL } \\
\text { EXPERIENCE }\end{array}$} & $1-5$ & $\begin{array}{c}6 \\
24,00\end{array}$ & $\begin{array}{c}6 \\
21,43\end{array}$ & $\begin{array}{c}10 \\
22,73\end{array}$ & \multirow{4}{*}{$\begin{array}{c}X 2=5.192 \\
D F=6 \\
P \quad 0.51\end{array}$} \\
\hline & $5-10$ & $\begin{array}{c}9 \\
36,00\end{array}$ & $\begin{array}{c}6 \\
21,43\end{array}$ & $\begin{array}{c}10 \\
22,73\end{array}$ & \\
\hline & $10-20$ & $\begin{array}{c}9 \\
36,00\end{array}$ & $\begin{array}{c}9 \\
32,14\end{array}$ & $\begin{array}{c}15 \\
34,09\end{array}$ & \\
\hline & 20 AND MORE & $\begin{array}{c}1 \\
4,00\end{array}$ & $\begin{array}{c}7 \\
25,00\end{array}$ & $\begin{array}{c}9 \\
20,45\end{array}$ & \\
\hline \multirow{3}{*}{ ACADEMIC RANK } & $\begin{array}{c}\text { ASSOCIATES AND } \\
\text { TEACHING } \\
\text { FELLOWS }\end{array}$ & $\begin{array}{c}14 \\
56,00\end{array}$ & $\begin{array}{c}13 \\
46,43\end{array}$ & $\begin{array}{c}25 \\
56,82\end{array}$ & \multirow{3}{*}{$\begin{array}{c}\mathrm{X} 2=1.899 \\
\mathrm{DF}=4 \\
\text { P } 0.75\end{array}$} \\
\hline & DOCENTS & $\begin{array}{c}8 \\
32,00\end{array}$ & $\begin{array}{c}8 \\
28,57\end{array}$ & $\begin{array}{c}12 \\
27,27\end{array}$ & \\
\hline & $\begin{array}{c}\text { ASSOCIATE AND } \\
\text { TENURED } \\
\text { PROFESSORS }\end{array}$ & $\begin{array}{c}3 \\
12,00\end{array}$ & $\begin{array}{c}7 \\
25,00\end{array}$ & $\begin{array}{c}7 \\
15,91\end{array}$ & \\
\hline \multirow{4}{*}{$\begin{array}{c}\text { NUMBER OF PUBLISHED } \\
\text { WORKS }\end{array}$} & UP TO 10 & $\begin{array}{c}9 \\
36,00\end{array}$ & $\begin{array}{c}6 \\
21,43\end{array}$ & $\begin{array}{c}17 \\
38,64\end{array}$ & \multirow{4}{*}{$\begin{array}{c}\mathrm{X} 2=3.771 \\
\mathrm{DF}=6 \\
\text { P } 0.70\end{array}$} \\
\hline & $10-20$ & $\begin{array}{c}5 \\
20,00\end{array}$ & $\begin{array}{c}3 \\
10,71\end{array}$ & $\begin{array}{c}8 \\
18,18\end{array}$ & \\
\hline & $20-50$ & $\begin{array}{c}7 \\
28,00\end{array}$ & $\begin{array}{c}10 \\
35,72\end{array}$ & $\begin{array}{c}11 \\
25,00\end{array}$ & \\
\hline & 50 AND MORE & $\begin{array}{c}3 \\
12,00\end{array}$ & $\begin{array}{c}6 \\
21,43\end{array}$ & $\begin{array}{c}8 \\
18,18\end{array}$ & \\
\hline IN TOTAL & & $\begin{array}{c}25 \\
25,77\end{array}$ & $\begin{array}{c}28 \\
28,87\end{array}$ & $\begin{array}{c}44 \\
45,36\end{array}$ & \\
\hline
\end{tabular}

TABLE 2: EXTRINSIC MOTIVATION AND THE QUALITY OF SCIENTIFIC RESEARCH 


\section{B) QUANTITATIVE METHODS FOR THE EVALUATION OF SCIENTIFIC RESEARCH AND THE AUTONOMY OF THE RESEARCHER}

The focus of this segment of the research is on whether existing quantitative methods for the evaluation of scientific research negatively affect the autonomy of the researcher in terms of choice of the desired research problems and the appropriate time for the researcher.

More than a half of teachers and associates $(55,67 \%)$ perceive a negative correlation between quantitative methods for the evaluation of scientific research and their own autonomy as researchers. Slightly less than one fifth of respondents disagree (19,59\%), whereas approximately one quarter or $24,74 \%$ are undecided.

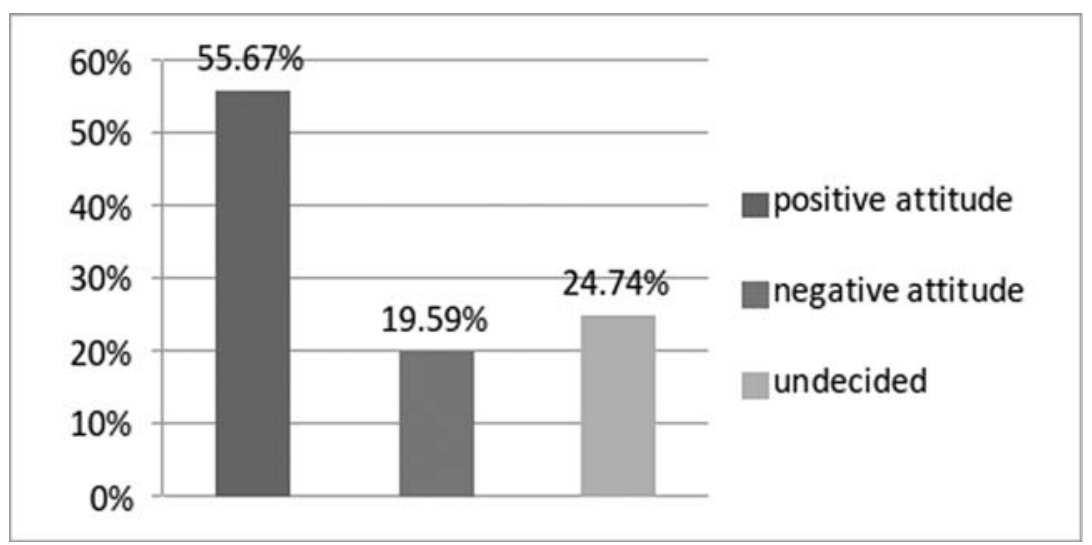

CHART 3: QUANTITATIVE METHODS FOR THE EVALUATION OF SCIENTIFIC RESEARCH AND THE AUTONOMY OF THE RESEARCHER

Unlike the previous two research tasks where independent variables proved irrelevant, we noticed a difference in attitudes of teachers and associates in relation to the university they belong to and their professional experience. Other variables proved statistically insignificant.

\begin{tabular}{|c|c|c|c|c|c|c|c|}
\hline \multirow{2}{*}{$\begin{array}{l}\text { ATTITUDES/ } \\
\text { INDEPENDENT } \\
\text { VARIABLES }\end{array}$} & & $\mathrm{VE}$ & & DED & & & \multirow{2}{*}{$\begin{array}{l}\text { STATISTICAL } \\
\text { INDICATORS }\end{array}$} \\
\hline & $\mathrm{F}$ & $\%$ & $\mathrm{~F}$ & $\%$ & $\mathrm{~F}$ & $\%$ & \\
\hline
\end{tabular}

TABLE 3: QUANTITATIVE METHODS FOR THE EVALUATION OF SCIENTIFIC RESEARCH AND THE AUTONOMY OF THE RESEARCHER 
Collection of Papers of the Faculty of Philosophy XLVI (3)/2016

\begin{tabular}{|c|c|c|c|c|c|}
\hline \multirow{3}{*}{ UNIVERSITY } & KRAGUJEVAC & $\begin{array}{c}7 \\
36,84\end{array}$ & $\begin{array}{c}8 \\
33,33\end{array}$ & $\begin{array}{c}22 \\
40,74\end{array}$ & \multirow{3}{*}{$\begin{array}{c}\mathrm{X} 2=9.332 \\
\mathrm{DF}=4 \\
\mathrm{P}<0.05\end{array}$} \\
\hline & BELGRADE & $\begin{array}{c}11 \\
57,89\end{array}$ & $\begin{array}{c}13 \\
54,17\end{array}$ & $\begin{array}{c}16 \\
29,63\end{array}$ & \\
\hline & Niš & $\begin{array}{c}1 \\
5,26\end{array}$ & $\begin{array}{c}3 \\
12,50\end{array}$ & $\begin{array}{c}16 \\
29,63\end{array}$ & \\
\hline \multirow{4}{*}{$\begin{array}{c}\text { YEARS OF } \\
\text { PROFESSIONAL } \\
\text { EXPERIENCE }\end{array}$} & $1-5$ & $\begin{array}{c}2 \\
10,53\end{array}$ & $\begin{array}{c}8 \\
33,33\end{array}$ & $\begin{array}{c}12 \\
22,22\end{array}$ & \multirow{4}{*}{$\begin{array}{c}\mathrm{X} 2=15.20 \\
\mathrm{DF}=6 \\
\mathrm{P} \quad<0.05\end{array}$} \\
\hline & $5-10$ & $\begin{array}{c}7 \\
36,84\end{array}$ & $\begin{array}{c}3 \\
12,50\end{array}$ & $\begin{array}{c}15 \\
27,78\end{array}$ & \\
\hline & $10-20$ & $\begin{array}{c}8 \\
42,10\end{array}$ & $\begin{array}{c}4 \\
16,67\end{array}$ & $\begin{array}{c}21 \\
38,89\end{array}$ & \\
\hline & 20 AND MORE & $\begin{array}{c}2 \\
10,53\end{array}$ & $\begin{array}{c}9 \\
37,50\end{array}$ & $\begin{array}{c}6 \\
11,11\end{array}$ & \\
\hline \multirow{3}{*}{ ACADEMIC RANK } & $\begin{array}{l}\text { ASSOCIATES AND } \\
\text { TEACHING FELLOWS }\end{array}$ & $\begin{array}{c}6 \\
31,58\end{array}$ & $\begin{array}{c}13 \\
54,17\end{array}$ & $\begin{array}{c}30 \\
55,56\end{array}$ & \multirow{3}{*}{$\begin{array}{c}X 2=5.57 \\
D F=4 \\
P=0.23\end{array}$} \\
\hline & DOCENTS & $\begin{array}{c}9 \\
47,37\end{array}$ & $\begin{array}{c}5 \\
20,83\end{array}$ & $\begin{array}{c}17 \\
31,48\end{array}$ & \\
\hline & $\begin{array}{c}\text { ASSOCIATE AND } \\
\text { TENURED } \\
\text { PROFESSORS }\end{array}$ & $\begin{array}{c}4 \\
21,05\end{array}$ & $\begin{array}{c}6 \\
25,00\end{array}$ & $\begin{array}{c}7 \\
12,96\end{array}$ & \\
\hline \multirow{4}{*}{$\begin{array}{c}\text { NUMBER OF } \\
\text { PUBLISHED PAPERS }\end{array}$} & UP то 10 & $\begin{array}{c}5 \\
26,32\end{array}$ & $\begin{array}{c}9 \\
37,50\end{array}$ & $\begin{array}{c}18 \\
33,33\end{array}$ & \multirow{5}{*}{$\begin{array}{c}\mathrm{X} 2=7.997 \\
\mathrm{DF}=6 \\
\mathrm{P}=0.23\end{array}$} \\
\hline & $10-20$ & $\begin{array}{c}4 \\
21,04\end{array}$ & $\begin{array}{c}2 \\
8,33\end{array}$ & $\begin{array}{c}14 \\
25,93\end{array}$ & \\
\hline & $20-50$ & $\begin{array}{c}5 \\
26,32\end{array}$ & $\begin{array}{c}6 \\
25,00\end{array}$ & $\begin{array}{c}17 \\
31,48\end{array}$ & \\
\hline & 50 AND MORE & $\begin{array}{c}5 \\
26,32\end{array}$ & $\begin{array}{c}7 \\
29,17\end{array}$ & $\begin{array}{c}5 \\
9,26\end{array}$ & \\
\hline \multicolumn{2}{|c|}{ IN TOTAL } & $\begin{array}{c}19 \\
19,59\end{array}$ & $\begin{array}{c}24 \\
24,74\end{array}$ & $\begin{array}{c}97 \\
55,67\end{array}$ & \\
\hline
\end{tabular}

TABLE 3: QUANTITATIVE METHODS FOR THE EVALUATION OF SCIENTIFIC RESEARCH AND THE AUTONOMY OF THE RESEARCHER

It is interesting that the employees at the University of Kragujevac were the most critical in their assessment of the negative 
correlation between their own autonomy as researchers and quantitative methods for the evaluation of scientific research - 40,74\% share that attitude. They are followed by teachers and associates from the universities of Belgrade and Nišs, who have exactly the same percentage $(29,63 \%)$. More than half respondents who work at the University of Belgrade $(54,17 \%)$ are undecided regarding this question.

More than a half $(57,89 \%)$ of teachers and associates from the University of Belgrade believe that existing quantitative methods for the evaluation of scientific research don't have a negative impact on the autonomy of the researcher.

The variable professional experience also proved statistically significant within this research task. Most respondents who positively assessed the correlation between quantitative methods for the evaluation of scientific research and their own autonomy as researchers have a professional experience in the range of 10-20 years $(42,10 \%)$. It is interesting that respondents who disagree on this matter belong to the same group $(38,89 \%)$. The percentage of teachers and associates who positively assess the correlation between quantitative indicators and their own autonomy as researchers, and whose professional experience is in the range of 5-10 years, is not negligible either $(36,84 \%)$. Most undecided respondents belong to the categories of most experienced $(37,50 \%)$ and least experienced $(33,33 \%)$ teachers and associates.

\section{DISCUSSION OF RESULTS}

The comparative analysis of the research results inevitably encounter serious difficulties, because this kind of research is almost non-existent. That is why we are discussing research results relying significantly more than usual on literature education and professional development of professors. In addition, it is not at all simple quantitative results of the external evaluation, which are more a result of education policy, to bring into line with the results of research based on sound scientific methodology. We believe that these are the main reasons for the positive and neutral attitudes toward quantitative methods of evaluation of scientific research are so polarized and that is why $27 \%$ of the professors that approach assess this negatively. 
A particular problem is the comparison of results of research of this kind with the results of the survey of foreign researchers because the evaluation criteria of scientific work of university professors in different social systems is different and with more or less scientific foundation.

It should be borne in mind that the extrinsic motivation of professors for scientific research and advancement in higher scientific positions, relative to intrinsic motivation, does not give the desired results. This confirms the views of almost half or $45 \%$ of the professors. Only one quarter of professors, about $25 \%$, have a positive attitude towards this kind of external motivation, and more than that, or $28 \%$, of the professors remained undecided.

In the circumstances of quantitative evaluation of scientific work of professors, professors lose their autonomy in the design and evaluation of its own scientific research work. This attitude is more than polyvinyl or $50 \%$ of the surveyed professors. One quarter, or $25 \%$ of the professors is neutral while slightly less than one-fifth, or around $25 \%$ of professors have a positive attitude towards the existing external system of evaluation of scientific work of professors.

As scientific research variables are concerned, they did not affect the results of research, except in the case of integration of quantitative assessment methods of evaluation of scientific research and the autonomy of researchers. There is significant difference between the attitudes of professors of different universities. According to this method of quantitative evaluation and its impact on the autonomy of the researchers, the most critical professors are at Kragujevac University. It is assumed that the criteria of evaluation of scientific research and the selection of professors is strictest in the administration at this university. It was also shown that work experience of professors partially affects research results. Professors working from 10 to 20 years of assessing quantitative practices and procedures of scientific research and the autonomy of researchers rate them most positively, followed by professors with experience of 5 to 10 years. It is likely that more experienced professors are more cautious in assessing the external system because they introduced different systems of evaluation, making them able to compare them. 
Lifelong learning is a continuous and permanent process, an essential requirement of every individual's active and creative participation in daily life, but also a key platform for professional development of every individual, including the professional development of university teachers and associates. The nature of extrinsic motivation, methods and criteria for the evaluation of scientific research determine the character and quality of professional development of university teachers and associates to a great extent.

In accordance with the new educational policy, quantitative methods for the evaluation of scientific research done by teachers and associates have become an important requirement of their professional development, defined both in state legislation and university acts, especially in rules and standards on self-assessment and quality review of higher education institutions and regulations on election and appointment of teachers and associates. It is a complex phenomenon that exists in pedagogical science and teaching practice alike.

Dealing with one segment of this very broad issue, the empirical part of this paper puts special emphasis on examining the perception of university teachers and associates about the impact of quantitative methods for the evaluation of scientific research on the quality of their own scientific research on the one hand, and the correlation between the quality of scientific research and normative acts of the university and the autonomy of the researcher on the other.

Judging by the attitudes of teachers and associates at teacher training faculties, the general assessment is that quantitative methods for the evaluation of scientific research indeed contribute to the quality of teaching and motivation for scientific research, but not to a sufficient extent. However, results of the research also show that there is a negative impact on the autonomy of the researcher in terms of the choice of their research content and time dynamics. Results we obtained imply that a new, more comprehensive research focused on examining teachers' opinions about the character and reasons for (in)efficiency of quantitative indicators of scientific work is required. 
REFERENCES Alibabić, Š. (2010). Univerzitetski profesor: naučnik i/ili nastavnik. Andragoškestudije, 2, 79-100.

Avramović, Z. (2014). Problemi inovacije u radu univerzitetskog nastavnika. Beograd: Institut za pedagoška istraživanja. Dostupno na http://kpolisa.com/ KP25/kp25-V-2-Avramovic.pdf

Грандић, Р., Стипић, М. (2011). Професионални развој наставника - пут

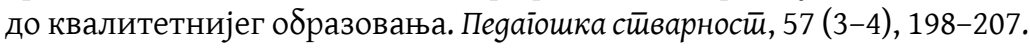

Хебиб, Е. (1995). Вредновање рада наставника - једна компонента

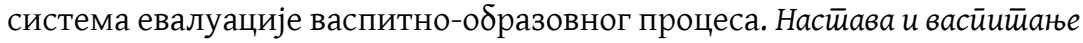
44(1-1), 83-95.

Ivić, I., Pešikan, A., Antić, S. (2003). Aktivno učenje. Beograd: Institut za psihologiju.

Jovanović Ivić, M. (1971). „Savremene tendencije obrazovanja i samoobrazovanja". U: M. Jovanović (prir. i ur.), Zbornik 4 (str. 10-19) Beograd: Institut za pedagoška istraživanja.

Marinković, S. (2010). Profesionalni razvoj nastavnika i postignuća učenika. Užice: Učiteljski fakultet.

Ogienko, O., Rolyak, A. (2009). "Model of Professional Teachres Competences Formation: European Dimension".Teacher Education Policy in Europe (TEPE) Network, TEPE 2009 Conference, Umea University.

Pešić, M. (1998). „Samoevaluacija praktičara”. U. M. Pešić (prir. u ur.), Pedagogija u akciji: metodološki priručnik (143-163). Beograd: Institut za pedagogiju i andragogiju Filozofski fakultet.

Popović, K., Vujisić Živković, N. (2012): Kvantitativni pristup vrednovanju kvaliteta istraživanja u oblasti obrazovanja - otvorena pitanja, problemi i perspektive. Andragoške studije, br. 2, 23-42.

Potkonjak, N. (1972). Vrednovawe rada osnovnih škola: potrebe, mogućnosti, iskustva. Beograd: Jugoslovenski zavod za proučavanje prosvetnih i školskih pitanja.

Prodanović, T. (1971). „Funkcija samoobrazovanja u profesionalnom usavršavanju". U: M. Jovanović (prir. i ur.), Zbornik 4 (str. 62-72) Beograd: Institut za pedagoška istraživanja

Stanković, D., Pavlović, J. (2010). „Modeli profesionalnog razvoja nastavnika". U:N. Polovina i J. Pavlović (prir. i ur.), Teoruja i praksa profesionalnog razvoja nastavnika (str. .17-40) Beograd: Institut za pedagoška istraživanja.

Vasilijević, D. (2010). Individualno stručno usavršavanje nastavnika. Užice: Učiteljski fakultet. 
Vasilijević, D., Sudzilovski, D. (2016). „Uticaj naučnoistraživačkog rada na profesionalni razvoj univerzitetskih nastavnika i kvalitet nastavnog rada". U: S. Denić (prir. u ur.), Godišnjak Pedagoškog fakulteta u Vranju (str. 139-152). Vranje: Pedagoški fakultet. 
ДАНИЈЕЛА Н. ВАСИЛИЈЕВИЋ

ДАНИЈЕЛА М. СУДЗИЛОВСКИ

СНЕЖАНА S. МАРИНКОВИТ

УНИВЕРЗИТЕТ У КРАГУЈЕВЦУ

УчИТЕљСКИ ФАКУЛТЕТ У УЖИЦУ

РЕЗИМЕ

УТИЦАЈ КВАНТИТАТИВНИХ ПОСТУПАКА НА КВАЛИТЕТ

НАУЧНОИСТРАЖИВАЧКОГ РАДА УНИВЕРЗИТЕТСКИХ НАСТАВНИКА

У теоријском оквиру рада разматра се питање професионалног развоја универзитетскох наставника у контексту целоживотног учења, указује на карактер актуалног вредновања њиховог научно-истраживалког рада, као и значај и ефекекте законске регулативе усмерене на поступке и начине квантитативног вредновања научно истраживачког рада универзитетских наставника и сарадника. Методолошки оквир истраживања утемељен је на научноистраживачком циљу оријентисаном на испитивање ставова наставника и сарадника учитељских факултета о доприносу квантитативних поступака и начина вредновања квалитету професионалног развоја и квалитету научно-истраживачког рада наставника и сарадника учитељских факултета. Општи циљ истраживања је конкретизован кроз два научноистраживачка задатка: 1) испитати како наставници учитељских факултета опажају утицај квантитативних поступака и начина вредновања научноистраживачког рада на квалитет властитог научно-истраживачког рада; 2) установити како наставници оцењују повезаност квалитета научно-истраживачког рада са нормативним актима универзитета везаним за избор у наставничка звања; 3) утврдити да ли и у којој мери постојећи квантитативни поступци и начини вредновања утичу на аутономију истраживача у погледу избора истраживачких садржаја и вре,енске динамике. Применом дескриптивне методе, Ликертовом скалом судова испитани су и анализирани ставови 97 наставника и сарадника учитељских факултета у Ужицу, Београду, Врању, Јагодини. Показало се да квантитативни поступци и начини вредновања, према ставовима наставника и сарадника учитељских факултета, доприносе, али не у довољној мери квалитету наставног рада и професионалном развоју наставника и сарадника.

Кључне речи: професионални развој наставника, научноистраживачки рад, вредновање, квантитативни поступци, квалитет рада. 